\title{
Comparative study: International chain and local chain hotel COVID-19 readiness strategies in Indonesia
}

\section{Yoanita Alexandra, Purnamaningsih (D), Septi Fahmi Choirisa}

Faculty of Business, Universitas Multimedia Nusantara,

Tangerang, Indonesia

yoanita.alexandra@umn.ac.id; purnamaningsih@umn.ac.id; septi.choirisa@umn.ac.id

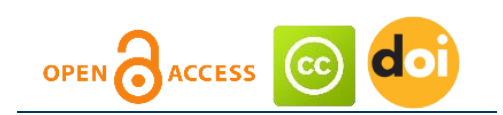

Article history:

Received: September 21, 2021

1st Revision: October 12, 2021

Accepted: November 24, 2021

\section{JEL classification: L83}

\section{DOI:}

10.14254/jems.2021.6-2.9

\begin{abstract}
The global hospitality and tourism industry has been severely impacted by the spread of COVID-19 and large-scale travel restrictions. Due to the nature of the crisis of COVID-19, Hotel businesses in Indonesia need to adapting many new strategies in response to the evolving circumstances. This study presents a comparative coronavirus readiness strategy at International Chain Hotel and Local Hotel in Indonesia and their impacts on hotel guests' trust and satisfaction. The study used quantitative approaches by using an online survey to obtain data from a total of 400 participants. The data were collected from respondents that have been stayed in both the International Chain hotel or Local Chain Hotel in Indonesia during pandemics. The data collected is analyzed using Structural Equation Modeling (SEM) with Smart PLS statistical software. The findings from this dataset show that both local and international hotel readiness had a significant effect on customer trust and satisfaction with COVID19 readiness in the hotel industry.
\end{abstract}

Keywords: COVID-19, hotel chain, hotel readiness, customer satisfaction, customer trusts.

\section{Introduction}

The COVID-19 outbreak has impacted the global hospitality and tourism industry. The travel restrictions, government regulations, and tourists are more aware of a high level of risk when traveling for tourism purposes (Awan \& Shamim, 2020). The hotel business conditions had dropped dramatically, however, it slowly showing improvement along with loosening travel restrictions provided by the Government to the community. The figure then dropped again coinciding with the implementation of Large-Scale Social Restrictions by the Government (Azanella, 2020).

Both international chain and local chain hotels are attempting to maintain relationships with key constituencies while focusing on an organization's survival during a crisis. In response to the evolving COVID-19 crisis, the hospitality industry is implementing a many new strategies. Significant changes are brought about by restructuring and downsizing of workers (Hao, Xiao, \& Chon, 2020);

Corresponding author: Yoanita Alexandra

E-mail: yoanita.alexandra@umn.ac.id

This open access article is distributed under a Creative Commons Attribution (CC-BY) 4.0 license. 
the efficiencies of operational cost and tight budgeting (Hotel Business, 2020); drastic operational changes, including changes in service delivery methods (Alonso, et al., 2020); adoption of new technology (Baum, Mooney, Robinson, \& Solnet, 2020); and compliance with new health protocols, hygiene and safety standards (Sigala, 2020).

People were obliged to live differently as a result of the pandemic; a lifestyle adjustment included social isolation or social distancing and working from home (Ratten, 2020). This situation is referred to as the 'New Normal,' which is described as the situation during and/or after a pandemic in which health protocols are made essential in all facets of daily human activities. In addition to the government's decisions, the majority of large corporations have a special involvement in supporting national economies and consumer welfare (Fadel, Descatha, \& Salomon, 2020). Businesses particularly those in the service industry; such as hospitality businesses are striving to provide excellent service in order to retain the existing customers and attract new ones. However, due to the uncertain nature of the COVID-19 pandemic, being able to keep up with the excellent service is more complicated than before (Tarki, Levy, \& Weiss, 2020).

This paper measures hotels' responses to the pandemic with several new dimensions and compared between the local chain and international chain hotel. International chain hotels and local chains have a different approach to readiness strategies, which brings into the differentiation of how the guest will be satisfied. In general, guest attachment to an international hotel brand brings more international demand, meanwhile local hotel chains are considered for their adaptability to local business conditions (Ribaudo, Moccia, Orero-Blat, \& Palacios-Marqués, 2020). Previous research on the effects of COVID-19 readiness strategies at F\&B stores in Jakarta found that customer satisfaction mediates the relationship between store readiness and the creation of trust. Customers were pleased with the new operational changes implemented by F\&B stores that are required to follow health protocols (Veronica, Prabowo, Manurung, \& Hamsal, 2020).

\section{Literature review}

Many studies have been done about hotel and hospitality industry sector strategies in Indonesia during pandemic of COVID-19. Study found by Situmorang and Japutra (2021), repercussions and challenges in hospitality industry during COVID-19 could turn into opportunities, however, the readiness strategies deployed by hotel managers could be detrimental in the future. Further, according to Ardani and Harianto (2021) to survive the crisis, hospitality business has to be aware with the government regulations, maintaining their human capital, creating innovation program and maintaining and developing networks. Many of the research focused on the readiness strategies from the management perspective, so this study sought to provide empirical research focusing on hotel' attempts to generate customer satisfaction in order to regain customer trust, in addition both for local and international chain hotel in Indonesia.

\subsection{Hotel readiness}

Hospitality companies especially Hotel industries are forced to change their operating strategies when crises situations such as the pandemic of COVID-19 happened. These pandemics raise the level of uncertainty and necessitate quick responses to avoid negative consequences (Ritchie \& Jiang, 2019). However, the previous study showed that the hospitality industry is lacking preparation for a crisis (Bremser, Alonso-Almeida, \& Llach, 2018), due to a lack of adequate resources (Mat Som \& Wang, 2014); as well as lack of knowledge and experience regarding how to act in such situation (Okumus \& Karamustafa, 2005; Richie, 2008)

Following the previous study, the term 'readiness' refers to any state of circumstances in which a company or an organization must be prepared and ready to accomplish (Veronica, Prabowo, Manurung, \& Hamsal, 2020). Therefore, Hotel COVID-19 readiness is the situation where the hotel is adhering to the health protocols published both by the government and World Health Organizations. The previous study in the retail store industry in South Africa also showed that when the store is sanitized their entrances, counters and shelves had a significant effect on customer satisfaction with the COVID-19 readiness of retail stores (Rukuni \& Maziriri, 2020).

\subsection{Customer satisfaction}

Customer satisfaction is a metric that measures the gap between visitors' expectations and their evaluation after consumption (Nunkoo, Teeroovengaduma, Ringle, \& Sunnassee, 2020). Customer satisfaction is a key measure for long-term organizational success (Anderson \& Mittal, 2000). It indicates the degree to which customers perceive that the firm's products and services are 
meeting their needs on a regular basis (Anderson \& Srinivasan, 2003). According to the previous study, overall satisfaction is a better predictor of a company's past, current, and future performance. (Wang \& Lo, 2003). The relationship between Hotel readiness and customer satisfaction is important to be addressed, as is practitioners' understanding various changes in customer perspective while staying at the Hotel during a pandemic situation (Rukuni \& Maziriri, 2020).

\subsection{Customer trusts}

Guests Loyalty, commitment, cooperation, competitive advantage, and high turnover are all associated with guest trust in an organization (Veronica, Prabowo, Manurung, \& Hamsal, 2020). Based on a previous study, it is stated that customer trust is positively impacted brand loyalty and satisfaction itself affects trust (Song, Wang, \& Han, 2019). Guest trust in the hotel they stay in is especially important in the pandemic situation, where there are compulsory health protocols in terms of hygiene and social distancing. Furthermore, in order to gain the trust of customers, they must first be satisfied. Guest trust is becoming increasingly important, particularly in times of high uncertainty, such as the COVID-19 Pandemic. A guest who has faith in a particular hotel brand will have a favorable attitude toward that brand. This trust may lead to the purchase of products or services and the development of brand loyalty (Aydin \& Özer, 2005; Sarwar, Abbasi, \& Pervaiz, 2012).

Therefore, the hypothesis for this study are as follows:

Ho1: Local Hotel Chain Customer Satisfaction positively impacts Customer Trust.

Ho2: International Hotel Chain Customer Satisfaction positively impacts Customer Trust.

Ho3: Local Hotel Chain Readiness positively impacts Customer Satisfaction.

Ho4: International Hotel Chain Readiness positively impacts Customer Satisfaction.

Ho5: Local Hotel Chain Readiness positively impacts Customer Trust.

Ho6: International Hotel Chain Readiness positively impacts Customer Trust.

Ho7: Customer Satisfaction significantly mediates the relationship between Local Chain Hotel readiness and Customer Trust

Ho8: Customer Satisfaction significantly mediates the relationship between International Chain Hotel readiness and Customer Trust

Figure 1: Research framework

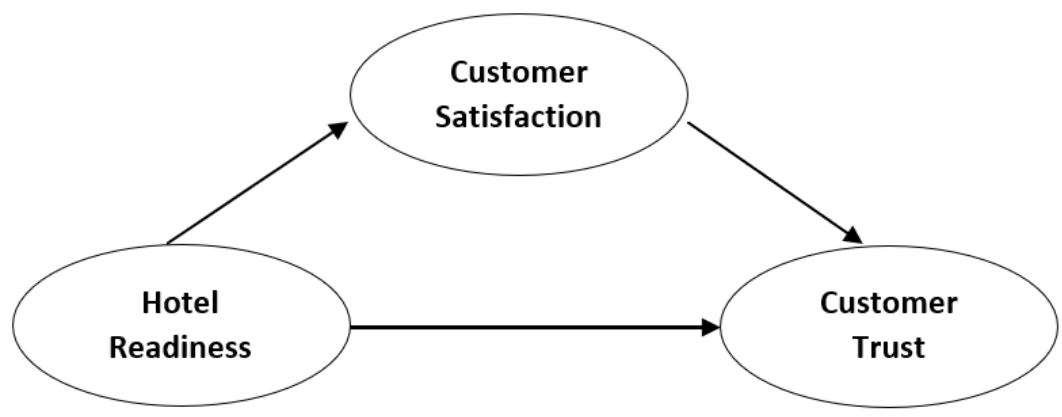

\section{Research methodology and data}

The research methodology used to conduct quantitative research was by distributing online questionnaires through email in the second and third quarters of 2021. The survey was sent to people that have experienced staying at the hotel, either local or international chain during the pandemic. The questionnaire consists of 23 questions: 7 questions about demographic factors and 16 variable questions using a Likert scale with the anchors of 1 (strongly disagree) to scale 5 (strongly agree). Since the focus of this study was hotel readiness strategies in new normal, respondents were asked whether they had stayed at the hotel in the pandemic era before they could proceed to the answer next questions in the survey. This study analysed in total 400 questionnaires, 200 respondents on each local or international hotel chain. This study was tested using Structural Equation Modelling (SEM) using software Smart PLS 3. 
Table 1: Measurement table

\begin{tabular}{ll}
\hline Construct & Measurement \\
\hline Hotel Readiness & Sanitized Entrances \\
(Rukuni \& & Sanitized Counters \\
Maziriri, 2020) & Sanitized Furniture \\
& Social Distancing \\
& Mask and Temperature
\end{tabular}

Items

Local/International Hotel Chain has shown sanitized entrances and lobby.

Local/International Hotel Chain has shown sanitized reception counters.

Local/International Hotel Chain has shown sanitized furniture in public areas (tables, chairs, and sofas.)

Local/International Hotel Chain has shown sanitized high contact area (door handles, restroom, elevator buttons, stair railings, restaurant, etc.)

Local/International Hotel Chain has shown sanitized Guestrooms.

Local/International Hotel Chain always makes sure to implement social distancing inside the hotel public area.

Local/International Hotel Chain makes sure their visitors have a mask on and have their temperature checked.

$\begin{array}{ll}\text { Customer } & \text { Expectation } \\ \text { Satisfaction } & \text { Product and Services } \\ \text { (Alshibly, 2015) } & \text { Experiences } \\ & \text { Needs } \\ & \text { Performance }\end{array}$

Customer Trust Impression of hotel (Kim \& Park, promises 2013)
Good Interest

Community

Trustworthiness

Hotel Trustworthiness
The overall performance of the Local/International Hotel Chain meets customers' expectations during the new normal.

I am Satisfied with the products and services offered in the Local/International Hotel Chain during my stay in the new normal.

I made especially good experiences in this Local/International Hotel Chain during the new normal.

This Local/International Hotel Chain offers exactly what customers need during the new normal.

I feel satisfied with the Local/International Hotel Chain Performance during the new normal.

This Local/International Hotel Chain gives the impression that they keep promises to always keep their hotel clean and sanitized during new normal.

I believe Local/International Hotel Chain still has my best interest to stay during new normal.

I feel safe to stay in Local/International Hotel Chain during the new normal.

Overall Local/International Hotel Chain is still trustworthy during new normal

\section{Result and discussion}

The demographics confirmed that the responses included in the analysis were solely from individuals who had at least once visited a local or international hotel chain during the implementation of the new normal at the time of the survey. The demographic makeup of the respondents who stayed in local chain hotels during a pandemic are as follows: Male (39\%), Female (62\%), 18-24 years old (69\%), 25-35 years old (21\%), 36-45 years old (10\%), Single (80\%), Married (21\%), Domicile in Jakarta (21\%), Tangerang (23\%), Bandung/Bogor (11\%), Surabaya (5\%), Bali (9\%), Palembang (26\%) and others (7\%). On the other hand, the demographic of the respondents who stayed in international hotel chains during a pandemic are as follows: Male (46\%), Female (55\%), 18-24 years old (55\%), 25-35 years old (27\%), 36-45 years old (19\%), Single (67\%), Married (32\%), Divorced/Widowed (2\%), Domicile in Jakarta (29\%), Tangerang (34\%), Bandung/Bogor (9\%), Surabaya (6\%), Bali (8\%), Palembang (13\%) and others (3\%).

The majority of respondents chooses Santika Group brands (44\%) as their local hotel chain preferences to stay during the pandemic, meanwhile, the respondents who stayed in international hotel chains mostly prefer to stay in Accor Group Hotels (29\%) during the pandemic. Both international and local chain hotel respondents were staying mostly in Java island (40\%) and Kepulauan Sunda Kecil (NTB, NTT, Bali) for 29\%. The respondents' reason to stay during pandemics is mostly for holiday/staycation with $61 \%$ for local chain hotels and $66 \%$ for international chain hotel respondents. (See Appendix 1, 2: Table 2, 3) 
Table 4: Convergent validity and reliability

\begin{tabular}{|c|c|c|c|c|c|}
\hline Variables & $\begin{array}{c}\text { No. of } \\
\text { indicators }\end{array}$ & $\begin{array}{c}\text { Cronbach's } \\
\text { Alpha }\end{array}$ & rho_A & $\begin{array}{l}\text { Composite } \\
\text { Reliability }\end{array}$ & $\begin{array}{c}\text { Average } \\
\text { Variance } \\
\text { Extracted } \\
\text { (AVE) }\end{array}$ \\
\hline \multicolumn{6}{|l|}{ Local Chain Hotel } \\
\hline Customer Satisfaction & 5 & 0.899 & 0.900 & 0.926 & 0.713 \\
\hline Customer Trusts & 4 & 0.848 & 0.850 & 0.897 & 0.686 \\
\hline Hotel Readiness & 7 & 0.894 & 0.896 & 0.917 & 0.612 \\
\hline \multicolumn{6}{|c|}{ International Chain Hotel } \\
\hline Customer Satisfaction & 5 & 0.869 & 0.870 & 0.905 & 0.657 \\
\hline Customer Trusts & 4 & 0.862 & 0.863 & 0.907 & 0.708 \\
\hline Hotel Readiness & 7 & 0.882 & 0.889 & 0.909 & 0.590 \\
\hline
\end{tabular}

The determine the convergent validity of the measurement items in this study, the outer loadings of each indicator and average variance extracted (AVE) were evaluated (Fornell \& Larcker, 1981). According to Roldán \& Sánchez-Franco (2012), AVE values should be greater than 0.50. Table 4 shows all the variables above 0.50 , thus indicate an adequate convergent validity measurement.

Internal consistency reliability is then determined by assessing the value of Composite Reliability (CR) (Kamis, et al., 2020). CR scores need to be greater than 0.7 to ensure acceptable internal consistency (Hair Jr, Hult, Ringle, \& Sarstedt, 2016; Gefen, Straub, \& Boudreau, 2000). As appeared in Table 4, all values are above the minimum. Moreover, Cronbach's Alpha greater than 0.7 is also a unit of measurement of the reliability of items (Nunnally \& Bernstein, 1994). The Cronbach alpha values ranged from $0.848-0.926$; proving the scores are accepted.

Table 5: Discriminant validity for local chain hotel

Fornell-Larcker Criterion

\begin{tabular}{lccc}
\hline & Customer Satisfaction & Customer Trust & Hotel Readiness \\
\hline Customer Satisfaction & 0.844 & & \\
Customer Trust & 0.824 & 0.828 & \\
Hotel Readiness & 0.746 & 0.779 & 0.782 \\
\hline
\end{tabular}

Table 6: Discriminant validity for international chain hotel

Fornell-Larcker Criterion

\begin{tabular}{lccc} 
& & & \\
\hline & Customer Satisfaction & Customer Trust & Hotel Readiness \\
\hline Customer Satisfaction & 0.810 & & \\
Customer Trust & 0.838 & 0.842 & 0.768 \\
Hotel Readiness & 0.725 & 0.693 & \\
\hline
\end{tabular}

The Discriminant Validity in Tables 5 and 6 compare the AVE square root value with the construct correlation value (Hair Jr, Hult, Ringle, \& Sarstedt, 2016). Based on the value analysis, the results are acceptable. These values depicted the proposed research question with the research framework's validity (Kamis, et al., 2020). Cross loading analysis is then used to execute the correlations among the constructs values and the indicator standardised data (Gefen \& Straub, 2005). The results are shown in Tables 7 and 8 (Appendix 3 and 4). The cross-loading values demonstrate the validity of the measurement model. Table 9 and Figure 2 show the results of the hypothesis assessment for both local chain hotels and international chain hotels. 


\section{Figure 2: Structural model (Bootstrap)}

\section{Local Chain}

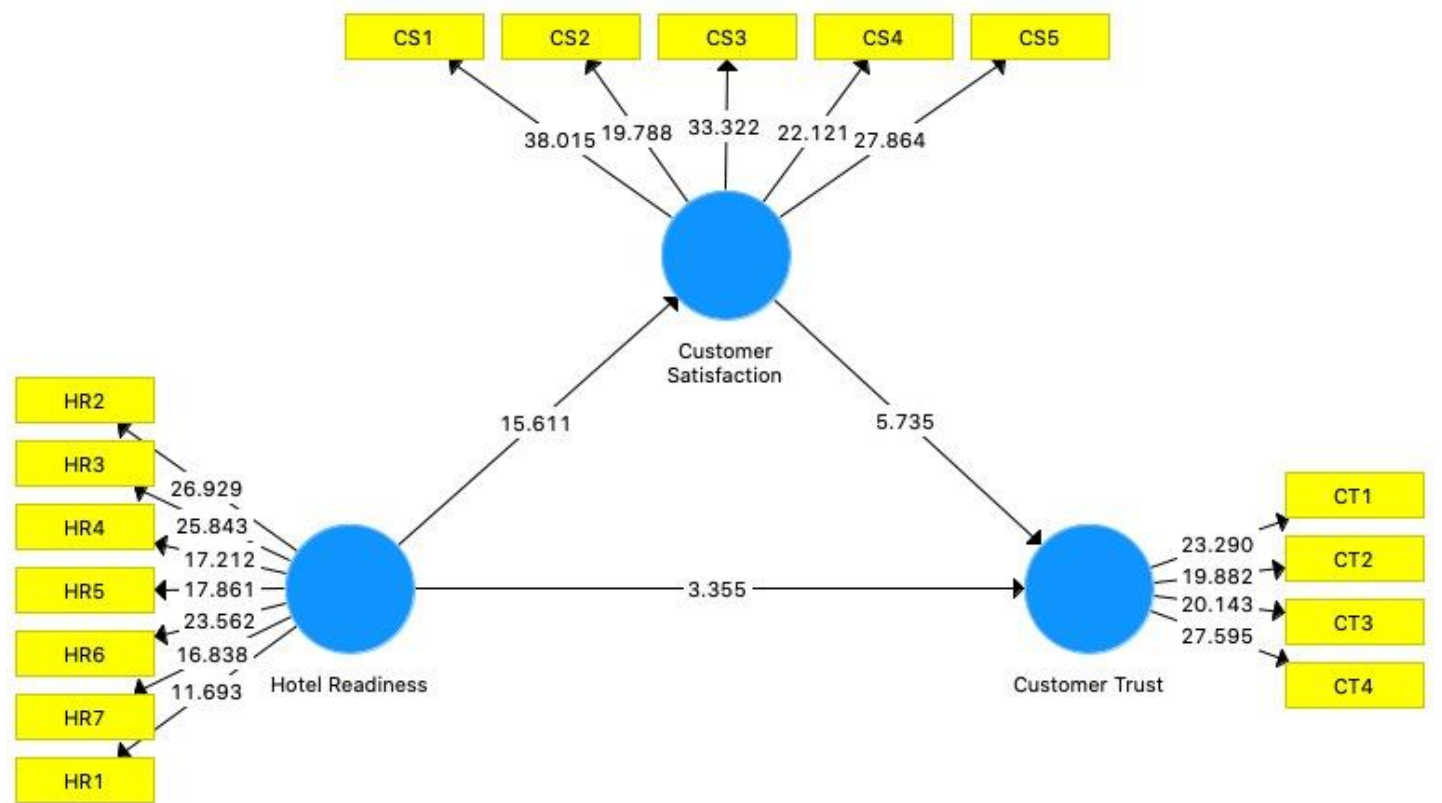

International Chain

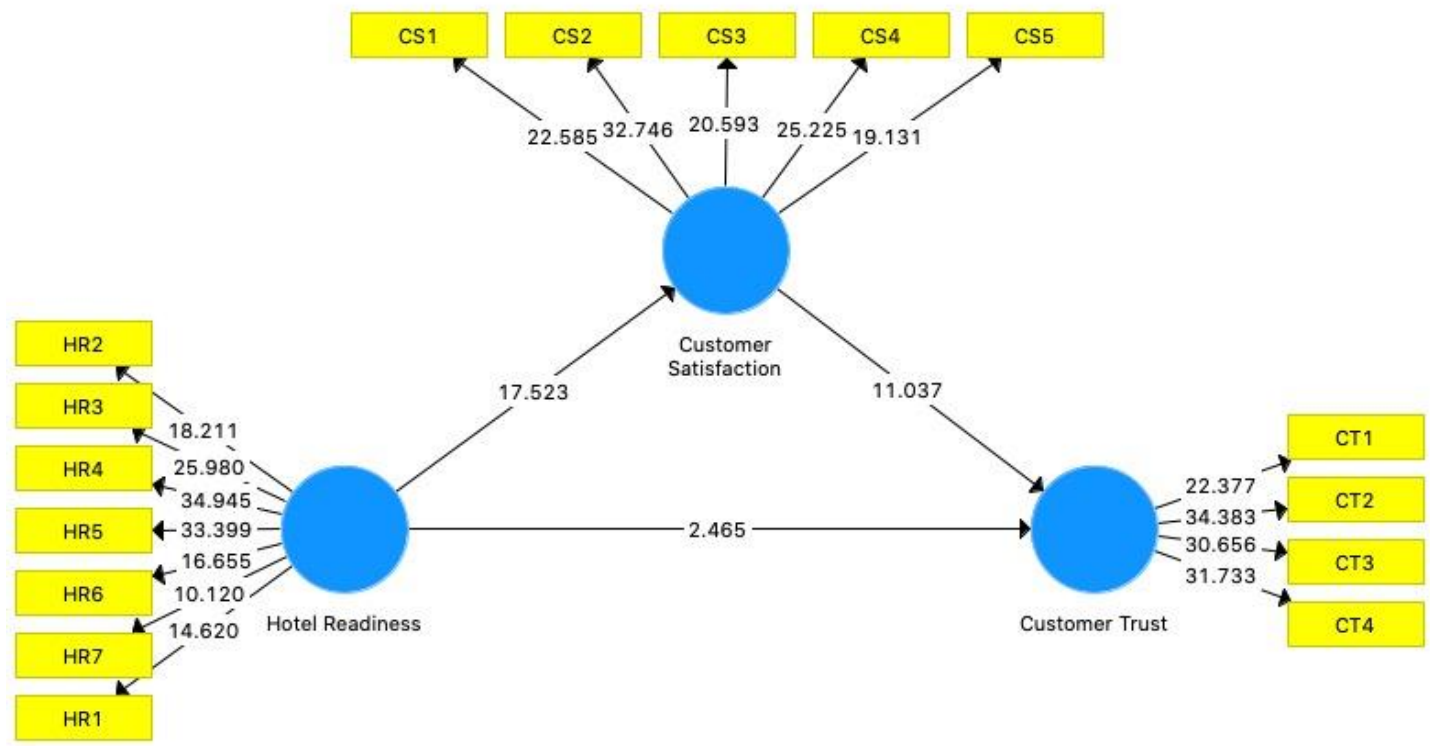

\section{Discussion}

The path coefficients identified the variables that are significantly affected. Table 9 shows that hotel readiness has the strongest effect on customer satisfaction (H3, H4) both for local chain (0.746) and international chain hotels $(0.725)$ followed by the effect of customer satisfaction on customer trusts $(\mathrm{H} 1, \mathrm{H} 2)$ for both local chain (0.548) and international chain hotel (0.708). This finding aligns with the findings of previous studies in a retail store in Africa that show a positive correlation between store readiness to customer satisfaction and also customer satisfaction (CS) has a significant and positive impact on customer trust (Rukuni \& Maziriri, 2020; Veronica, Prabowo, Manurung, \& Hamsal, 2020). Hotel readiness positively affected customer trust (H5, H6) for both local chain $(0.370)$ and international chain hotels $(0.181)$. In contrast, a previous study in a retail store during a pandemic showed that retail store readiness (RSR) has no significant impact on customer trust (Veronica, Prabowo, Manurung, \& Hamsal, 2020). Further, customer satisfaction significantly 
mediates the relationship between hotel readiness and customer trust, both on local chain hotel $(0.409)$ and international chain hotel (0.513) that show the hypothesis 7 and 8 are accepted.

\begin{tabular}{|c|c|c|c|c|}
\hline & Beta & T Values & P Values & Results \\
\hline \multicolumn{5}{|l|}{ Local Chain Hotel } \\
\hline $\begin{array}{l}\text { Customer Satisfaction > Customer } \\
\text { Trusts }\end{array}$ & 0.548 & 5.735 & 0.000 & significant \\
\hline $\begin{array}{l}\text { Hotel Readiness }>\text { Customer } \\
\text { Satisfaction }\end{array}$ & 0.746 & 15.611 & 0.000 & significant \\
\hline $\begin{array}{l}\text { Hotel Readiness }>\text { Customer Trusts } \\
\text { Hotel Readiness }>\text { Customer } \\
\text { Satisfaction }>\text { Customer Trusts }\end{array}$ & $\begin{array}{l}0.370 \\
0.409\end{array}$ & $\begin{array}{l}3.355 \\
4.586\end{array}$ & $\begin{array}{l}0.001 \\
0.000\end{array}$ & $\begin{array}{l}\text { significant } \\
\text { significant }\end{array}$ \\
\hline \multicolumn{5}{|l|}{ International Chain Hotel } \\
\hline $\begin{array}{l}\text { Customer Satisfaction > Customer } \\
\text { Trusts }\end{array}$ & 0.708 & 11.037 & 0.000 & significant \\
\hline $\begin{array}{l}\text { Hotel Readiness > Customer } \\
\text { Satisfaction }\end{array}$ & 0.725 & 17.523 & 0.000 & significant \\
\hline Hotel Readiness > Customer Trusts & 0.181 & 2.465 & 0.014 & significant \\
\hline $\begin{array}{l}\text { Hotel Readiness }>\text { Customer } \\
\text { Satisfaction }>\text { Customer Trusts }\end{array}$ & 0.513 & 8.659 & 0.000 & significant \\
\hline
\end{tabular}

The results of the study showed all hypotheses are positive and significant. However, between local hotel chains and international hotel chains, there is a relationship between variables that stronger than the others. In international hotel chains, the relations between hotel readiness and customer satisfaction and customer satisfaction to customer trust have higher significance value comparing to local hotel chains. On the other hand, local hotel chains showed that hotel readiness to customer trusts has more significant value than the international hotel chain.

Further, to answer the research question, this study calculated the $R$ squares $\left(R^{2}\right)$ of the research model. The $\mathrm{R}^{2}$ of customer trust with local chain hotels is 0.740 , which indicates that the variation can be accounted for $74 \%$. Meanwhile, the $\mathrm{R}^{2}$ of the customer satisfaction with local chain hotel variable is 0.557 or $56 \%$. On the other hand, the $\mathrm{R}^{2}$ of customer trusts with international chain hotels is 0.716 or $71 \%$, and the customer satisfaction with the international chain hotel is 0.530 or $53 \%$. This indicates that the merged essence of Expectation Disconfirmation Theory, Technology Acceptance Model, and Service Interaction successfully explains the Model for online learning satisfaction and e-loyalty.

\section{Conclusions and recommendations}

COVID-19's study of hotel chain readiness strategies reveals a novel research perspective in the event of a pandemic from the customer's point of view. This study attempts to provide an empirical study concentrating on the hotel industry's efforts to generate customer satisfaction to acquire customer trust. Even though the hotel industry showed a decrease in occupancy rate and having additional costs associated with providing health protocols, hotel industries must cope during this difficult period to survive. According to the findings, the guests' satisfaction mediates the relationship between hotel readiness and the formation of trusts.

The research findings in this study may be useful and provide insights for the hotel managers in order to build trust among guests. Further, the hotel readiness strategies must be met by the hotel and aligned with the government regulations. Hotel managers may consider new concepts in service delivery and modify standard operating procedures to comply with the new rules. This study could be evidence of how society especially young adults to travel domestically or across cities during the pandemic for a holiday or work-related activities, in contrast with the government regulation related to the tourism and travel restrictions. This situation shown could be used as a future study in terms of consumer behavior in the hotel industry during pandemic situations.

Moreover, forthcoming research should harness the qualitative aspects from hotel industry perspective, to estimate the future possibilities of hotel strategies to overcome difficult situation such as pandemics and gain further customer trusts. In addition, many of previous study are focusing more in retail store, therefore, it would be worthwhile to examine the strategies from the hotel industry. 


\section{Funding}

The author(s) received no financial support for the research, authorship, and/or publication of this article.

\section{Declaration of conflicting interests}

The author(s) declared no potential conflicts of interest with respect to the research, authorship, and/or publication of this article.

\section{Citation information}

Alexandra, Y., Purnamaningsih, \& Chikosha, F. (2021). Comparative study: International chain and local chain hotel COVID-19 readiness strategies in Indonesia. Economics, Management and Sustainability, 6(2), 119-131. doi:10.14254/jems.2021.6-2.9

\section{Reference}

Alonso, A. D., Kok, S. K., Bressan, A., O’Shea, M., Sakellarios, N., Koresis, A., ... \& Santoni, L. J. (2020). COVID-19, aftermath, impacts, and hospitality firms: An international perspective. International journal of hospitality management, 91, 102654., https://doi.org/10.1016/j.ijhm.2020.102654

Alshibly, H. H. (2015). Customer perceived value in social commerce: An exploration of its antecedents and consequences. Journal of Management Research, 7(1), 17-37. https://doi.org/doi:10.5296/jmr.v7i1.6800

Anderson, E. W., \& Mittal, V. (2000). Strengthening the satisfaction-profit chain. Journal of Service research, 3(2), 107-120. https://doi.org/10.1177\%2F109467050032001

Anderson, R. E., \& Srinivasan, S. S. (2003). E-satisfaction and e-loyalty: A contingency framework. Psychology \& marketing, 20(2), 123-138. https://doi.org/10.1002/mar.10063

Ardani, E. G., \& Harianto, A. (2021). Surviving strategy of hospitality sector in pandemic situation. EJournal of Tourism, 8(1), 77-86; https://doi.org/10.24922/eot.v8i1.71449

Awan, M. I., \& Shamim, A. (2020). Implementing 'cleanliness is half of faith' in re-designing tourists, experiences and salvaging the hotel industry in Malaysia during COVID-19 pandemic. Journal of Islamic Marketing, 12(3), 543-557. https://doi.org/10.1108/JIMA-08-2020-0229

Aydin, S., \& Ãzer, G. (2005). The analysis of antecedents of customer loyalty in the Turkish mobile telecommunication market. European Journal of Marketing,39(7-8), 910-925. https://doi.org/10.1108/03090560510601833

Azanella, L. A. (2020, September 26). Saat Pandemi Covid-19 Berdampak pada Bisnis Perhotelan Saat Ini. Retrieved from Kompas.com: https://www.kompas.com/tren/read/2020/09/26/102900465/saat-pandemi-covid-19berdampak-pada-bisnis-perhotelan-saat-ini?page=all

Baum, T., Mooney, S. K. K., Robinson, R. N. S., \& Solnet, D. (2020). COVID-19's impact on the hospitality workforce-new crisis or amplification of the norm?. International Journal of Contemporary Hospitality Management, 32(9), 2813-2829. https://doi.org/10.1108/IJCHM-04-2020-0314

Bremser, K., del Mar Alonso-Almeida, M., \& Llach, J. (2018). Strategic alternatives for tourism companies to overcome times of crisis. Service Business, 12(2), 229-251. https://doi.org/10.1007/s11628-017-0344-7

Fadel, M., Salomon, J., \& Descatha, A. (2020). Coronavirus outbreak: the role of companies in preparedness and responses. The Lancet Public Health, 5(4), e193. https://doi.org/10.1016/S2468-2667(20)30051-7

Fornell, C., \& Larcker, D. F. (1981). Evaluating structural equation models with unobservable variables and measurement error. Journal of marketing research, 18(1), 39-50.

Gefen, D., \& Straub, D. (2005). A practical guide to factorial validity using PLSGraph: Tutorial and annotated example. Communications of the Association for Information Systems, 16, 91-109. 
Gefen, D., Straub, D., \& Boudreau, M.-C. (2000). Structural equation modeling and regression: guidelines for research practice. Communications of the Association for Information Systems, 7(7), 1-78.

Ghaderi, Z., Mat Som, A. P., \& Wang, J. (2014). Organizational learning in tourism crisis management: An experience from Malaysia. Journal of Travel \& Tourism Marketing,31(5), 627-648. https://doi.org/10.1080/10548408.2014.883951

Hair Jr, J. H., Hult, G. T., Ringle, C. M., \& Sarstedt, M. (2016). A Primer on partial least squares structural equation modeling (PLS-SEM). London: Sage Publications.

Hao, F., Xiao, Q., \& Chon, K. (2020). COVID-19 and China's hotel industry: Impacts, a disaster management framework, and post-pandemic agenda. International journal of hospitality management, 90, 102636. https://doi.org/10.1016/j.ijhm.2020.102636

Hotel Business. (2020, March 19). Hotel Companies Implement Changes to Reduce COVID-19 Impact. Retrieved from hotelbusiness.com: https://www.hotelbusiness.com/hotel-companiesimplement-changes-to-reduce-covid-19-impact/

Japutra, A., \& Situmorang, R. (2021). The repercussions and challenges of COVID-19 in the hotel industry: Potential strategies from a case study of Indonesia. International Journal of Hospitality Management, 95, 102890. https://doi.org/10.1016/j.ijhm.2021.102890

Kamis, A., Saibon, R. A., Yunus, F. N., Rahim, M. B., Herrera, L. M., \& Montenegro, P. Y. (2020). The SmartPLS Analyzes Approach in Validity and Reliability of Graduate Marketability Instrument. Socia Psychology \& Education, 57(8), 987-1001.

Kim, S., \& Park, H. (2013). Effects of various characteristics of social commerce (s-commerce) on consumers' trust and trust performance. International Journal of Information Management, 33(2), 318-332, https://doi.org/10.1016/j.ijinfomgt.2012.11.006

Nunkoo, R., Teeroovengadum, V., Ringle, C. M., \& Sunnassee, V. (2020). Service quality and customer satisfaction: The moderating effects of hotel star rating. International Journal of Hospitality Management, 91, 102414. https://doi.org/10.1016/j.ijhm.2019.102414

Nunnally, J., \& Bernstein, I. (1994). Psychometric Theory (3rd ed.). New York: McGraw-Hill.

Okumus, F., \& Karamustafa, K. (2005). Impact of an economic crisis evidence from Turkey. Annals of tourism research, 32(4), 942-961. https://doi.org/10.1016/j.annals.2005.04.001

Ratten, V. (2020). Coronavirus (covid-19) and social value co-creation. International Journal of Sociology and Social Policy, https://doi.org/10.1108/IJSSP-06-2020-0237

Ribaudo, G., Moccia, S., Orero-Blat, M., \& Palacios-Marqués, D. (2020). Comparing chains versus independent hotels based on international sales: an exploratory study. Economic researchEkonomska istraživanja, 33(1), 2286-2304. https://doi.org/10.1080/1331677X.2019.1710719

Ritchie, B. (2008). Tourism disaster planning and management: From response and recovery to reduction and readiness. Current issues in Tourism, 11(4), 315-348. https://doi.org/10.1080/13683500802140372

Ritchie, B. W., \& Jiang, Y. (2019). A review of research on tourism risk, crisis and disaster management: Launching the annals of tourism research curated collection on tourism risk, crisis and disaster management.Annals of Tourism Research, 79, 102812. https://doi.org/10.1016/j.annals.2019.102812

Roldán, J. L., \& Sánchez-Franco, M. J. (2012). Variance-based structural equation modeling: Guidelines for using partial least squares in information systems research. In Research methodologies, innovations and philosophies in software systems engineering and information systems (pp. 193221). IGI Global. https://doi.org/10.4018/978-1-4666-0179-6.ch010

Rukuni, T. F., \& Maziriri, E. T. (2020). Data on corona-virus readiness strategies influencing customer satisfaction and customer behavioural intentions in South African retail stores. Data in brief, 31, 105818. https://doi.org/10.1016/j.dib.2020.105818

Sarwar, M. Z., Abbasi, K. S., \& Pervaiz, S. (2012). The effect of customer trust on customer loyalty and customer retention: A moderating role of cause related marketing. Global Journal of Management and Business Research, 12(6), 26-36. 
Sigala, M. (2020). Tourism and COVID-19: Impacts and implications for advancing and resetting industry and research. Journal of Business Research, 312-321, https://doi.org/10.1016/j.jbusres.2020.06.015

Song, H., Wang, J., \& Han, H. (2019). Effect of image, satisfaction, trust, love, and respect on loyalty formation for name-brand coffee shops. International Journal of Hospitality Management, 79, 50-59. https://doi.org/10.1016/j.ijhm.2018.12.011

Tarki, A., Levy, P., \& Weiss, J. (2020). The coronavirus crisis doesn't have to lead to layoffs. Harvard Business Review Digital. Retrieved, 4. https://hbr.org/2020/03/the-coronavirus-crisisdoesnt-have-to-lead-to-layoffs

Veronica, V., Prabowo, H., Manurung, A. H., \& Hamsal, M. (2020). The influence of food \& beverage retail store COVID-19 readiness strategies on customer satisfaction and trust. Advances in Transportation and Logistics Research, 3, 836-843. https://doi.org/10.25292/atlr.v3i0.342

Wang, Y., \& Lo, H. P. (2003). Customer-focused performance and the dynamic model for competence building and leveraging: A resource-based view. Journal of Management Development, 22(6), 483-526. 


\section{Appendix}

\section{Appendix 1}

Table 2: Demographics of subjects in local chain hotel $(\mathrm{N}=200)$

\begin{tabular}{|c|c|c|c|}
\hline Variable & Category & Frequencies & Percentages (\%) \\
\hline \multirow[t]{2}{*}{ Gender } & Male & 77 & $39 \%$ \\
\hline & Female & 123 & $62 \%$ \\
\hline \multirow[t]{3}{*}{ Age Group } & 18-24 years old & 138 & $69 \%$ \\
\hline & 25-35 years old & 42 & $21 \%$ \\
\hline & 36-45 years old & 20 & $10.0 \%$ \\
\hline \multirow[t]{3}{*}{ Marital Status } & Single & 159 & $80 \%$ \\
\hline & Married & 41 & $21 \%$ \\
\hline & Divorced/Widowed & 0 & $0 \%$ \\
\hline \multirow{7}{*}{ Domicile } & Jakarta & 41 & $21 \%$ \\
\hline & Tangerang & 46 & $23 \%$ \\
\hline & Bandung/Bogor & 21 & $11 \%$ \\
\hline & Surabaya & 9 & $5 \%$ \\
\hline & Bali & 18 & $9 \%$ \\
\hline & Palembang & 51 & $26 \%$ \\
\hline & Others & 14 & $7 \%$ \\
\hline $\begin{array}{l}\text { Local Hotel Chain } \\
\text { Group }\end{array}$ & $\begin{array}{l}\text { Santika Group (Amaris, Santika, Santika } \\
\text { Premiere, Ayana) }\end{array}$ & 87 & $44 \%$ \\
\hline \multirow[t]{8}{*}{ Preferences } & Aryaduta Hotels & 5 & $3 \%$ \\
\hline & Hotel Tentrem Group (Tentrem, Chanti) & 6 & $3 \%$ \\
\hline & The Alts & 14 & $7 \%$ \\
\hline & Padma Hotels (Padma hotel, Padma Resort) & 5 & $3 \%$ \\
\hline & $\begin{array}{l}\text { Parador Hotel \& Resorts (Atria, Ara, Fame, } \\
\text { Starlet, Fame) }\end{array}$ & 14 & $7 \%$ \\
\hline & Kagum Hotels (Serela, Zodiak) & 6 & $3 \%$ \\
\hline & PHM Hotels (The 101, The Haven) & 9 & $5 \%$ \\
\hline & Others & 54 & $27 \%$ \\
\hline \multirow[t]{5}{*}{$\begin{array}{l}\text { Location of } \\
\text { Staying }\end{array}$} & Java Island & 93 & $47 \%$ \\
\hline & Sumatra Island & 46 & $23 \%$ \\
\hline & Kalimantan Island & 3 & $2 \%$ \\
\hline & Sulawesi Island & 1 & $1 \%$ \\
\hline & Kepulauan Sunda Kecil (NTB, NTT, Bali, etc) & 57 & $29 \%$ \\
\hline \multirow[t]{4}{*}{ Reason to Stay } & Work-related Stay/Business Trip & 25 & $13 \%$ \\
\hline & $\begin{array}{l}\text { Family Events (Wedding, Visiting Relatives, } \\
\text { etc.) }\end{array}$ & 51 & $26 \%$ \\
\hline & Holiday/Staycation & 121 & $61 \%$ \\
\hline & Others & 3 & $2 \%$ \\
\hline
\end{tabular}




\section{Appendix 2}

\begin{tabular}{|c|c|c|c|}
\hline Variable & Category & Frequencies & Percentages (\%) \\
\hline \multirow[t]{2}{*}{ Gender } & Male & 91 & $46 \%$ \\
\hline & Female & 109 & $55 \%$ \\
\hline \multirow[t]{3}{*}{ Age Group } & 18-24 years old & 110 & $55 \%$ \\
\hline & 25-35 years old & 53 & $27 \%$ \\
\hline & $36-45$ years old & 37 & $19 \%$ \\
\hline \multirow[t]{3}{*}{ Marital Status } & Single & 133 & $67 \%$ \\
\hline & Married & 64 & $32 \%$ \\
\hline & Divorced/Widowed & 3 & $2 \%$ \\
\hline \multirow[t]{7}{*}{ Domicile } & Jakarta & 58 & $29 \%$ \\
\hline & Tangerang & 68 & $34 \%$ \\
\hline & Bandung/Bogor & 17 & $9 \%$ \\
\hline & Surabaya & 11 & $6 \%$ \\
\hline & Bali & 16 & $8 \%$ \\
\hline & Palembang & 25 & $13 \%$ \\
\hline & Others & 5 & $3 \%$ \\
\hline \multirow{8}{*}{$\begin{array}{l}\text { International } \\
\text { Chain } \\
\text { Preferences }\end{array}$} & $\begin{array}{l}\text { Archipelago International (Aston, Fave, } \\
\text { Alana) }\end{array}$ & 19 & $10 \%$ \\
\hline & Marriot International (Ritz Carlton, St. & & \\
\hline & $\begin{array}{l}\text { Regis, W Hotels, JW Marriot, Rennaissance, } \\
\text { Westin, Sheraton, Le Meredien) }\end{array}$ & 54 & $27 \%$ \\
\hline & $\begin{array}{l}\text { Accor Group (Mercure, Raffles, Sofitel, } \\
\text { Pullman, Swissotel, Novotel, Ibis, } \\
\text { Fairmont) }\end{array}$ & 58 & $29 \%$ \\
\hline & $\begin{array}{l}\text { Wyndham Hotel and Resorts (Wyndham, } \\
\text { Ramada) }\end{array}$ & 7 & $4 \%$ \\
\hline & $\begin{array}{l}\text { Interncontinental } \quad \text { Hotel } \quad \text { Groups } \\
\text { (Intercontinental, Indigo, Crowne Plaza) }\end{array}$ & 11 & $6 \%$ \\
\hline & $\begin{array}{l}\text { Kempinski Hotels (Hotel Indonesia } \\
\text { Kempinski, Apurva Kempinski) }\end{array}$ & 11 & $6 \%$ \\
\hline & Others & 40 & $20 \%$ \\
\hline \multirow[t]{5}{*}{ Location of Staying } & Java Island & 93 & $47 \%$ \\
\hline & Sumatra Island & 46 & $23 \%$ \\
\hline & Kalimantan Island & 3 & $2 \%$ \\
\hline & Sulawesi Island & 0 & $0 \%$ \\
\hline & $\begin{array}{l}\text { Kepulauan Sunda Kecil (NTB, NTT, Bali, } \\
\text { etc) }\end{array}$ & 58 & $29 \%$ \\
\hline \multirow[t]{4}{*}{ Reason to Stay } & Work-related Stay/Business Trip & 25 & $13 \%$ \\
\hline & $\begin{array}{l}\text { Family Events } \quad \text { (Wedding, Visiting } \\
\text { Relatives, etc.) }\end{array}$ & 44 & $22 \%$ \\
\hline & Holiday/Staycation & 128 & $64 \%$ \\
\hline & Others & 3 & $2 \%$ \\
\hline
\end{tabular}




\section{Appendix 3}

Table 7: Cross loading for local chain hotels

\begin{tabular}{lccc}
\hline & Customer Satisfaction & Customer Trust & Hotel Readiness \\
\hline CS1 & 0.872 & 0.715 & 0.664 \\
CS3 & 0.838 & 0.669 & 0.620 \\
CS4 & 0.858 & 0.670 & 0.682 \\
CS5 & 0.822 & 0.715 & 0.588 \\
CT1 & 0.831 & 0.710 & 0.595 \\
CT2 & 0.741 & 0.830 & 0.685 \\
CT3 & 0.705 & 0.819 & 0.645 \\
CT4 & 0.591 & 0.813 & 0.621 \\
HR2 & 0.680 & 0.850 & 0.625 \\
HR3 & 0.623 & 0.647 & 0.845 \\
HR4 & 0.565 & 0.637 & 0.816 \\
HR5 & 0.525 & 0.558 & 0.758 \\
HR6 & 0.596 & 0.610 & 0.761 \\
HR7 & 0.625 & 0.651 & 0.796 \\
HR1 & 0.593 & 0.567 & 0.758 \\
& 0.551 & 0.586 & 0.735 \\
\hline
\end{tabular}

\section{Appendix 4}

\begin{tabular}{lccc} 
Table 8: Cross loading for international hotel chain & \\
\hline & Customer Satisfaction & Customer Trust & Hotel Readiness \\
\hline CS1 & 0.775 & 0.666 & 0.549 \\
CS2 & 0.842 & 0.691 & 0.623 \\
CS3 & 0.822 & 0.696 & 0.530 \\
CS4 & 0.828 & 0.695 & 0.618 \\
CS5 & 0.782 & 0.649 & 0.612 \\
CT1 & 0.689 & 0.792 & 0.605 \\
CT2 & 0.710 & 0.862 & 0.540 \\
CT3 & 0.715 & 0.868 & 0.614 \\
CT4 & 0.708 & 0.842 & 0.574 \\
HR2 & 0.493 & 0.494 & 0.785 \\
HR3 & 0.585 & 0.561 & 0.813 \\
HR4 & 0.604 & 0.590 & 0.856 \\
HR5 & 0.628 & 0.592 & 0.840 \\
HR6 & 0.493 & 0.454 & 0.691 \\
HR7 & 0.490 & 0.431 & 0.652 \\
HR1 & 0.577 & 0.572 & 0.716 \\
\hline
\end{tabular}

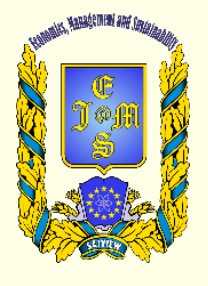

(c) 2016-2021, Economics, Management and Sustainability. All rights reserved.

This open access article is distributed under a Creative Commons Attribution (CC-BY) 4.0 license.

You are free to:

Share - copy and redistribute the material in any medium or format Adapt - remix, transform, and build upon the material for any purpose, even commercially.

The licensor cannot revoke these freedoms as long as you follow the license terms.

Under the following terms:

Attribution - You must give appropriate credit, provide a link to the license, and indicate if changes were made.

You may do so in any reasonable manner, but not in any way that suggests the licensor endorses you or your use.

You may do so in any reason
No additional restrictions

You may not apply legal terms or technological measures that legally restrict others from doing anything the license permits.

Economics, Management and Sustainability (ISSN: 2520-6303) is published by Scientific Publishing House "CSR",

Poland, EU and Scientific Publishing House "SciView", Poland

Publishing with JEMS ensures:

- Immediate, universal access to your article on publication

- High visibility and discoverability via the JEMS website

- Rapid publication

- Guaranteed legacy preservation of your article

- Discounts and waivers for authors in developing regions

Submit your manuscript to a JEMS at http://jems.sciview.net or submit.jems@sciview.net 